\title{
Gender and Climate Change: The Condition of Women in the Indian Sundarbans
}

\author{
Dr. Subarna Karmakar*
}

Assistant Teacher in Sociology, Baishnabnagar Vidyasagar Balika Vidyalaya (H.S.), Dist- Malda, West Bengal, India

DOI: $10.36347 /$ sjahss.2021.v09i01.001

| Received: 26.12.2020 | Accepted: 11.01.2021 | Published: 14.01.2021

*Corresponding author: Dr. Subarna Karmakar

Abstract

Original Research Article

Climate change is a threat to world's peace, security, and prosperity. The impacts of climate change are drought, flood, extreme weather, increased incidence of diseases, growing food insecurity and water insecurity which disproportionately distress 1.3 billion poor people of the globe and among them, the majority are women. The women of Sundarbans, India are not spared from the effect of climate change. Flood and sea level rise demolish crop production and cause sanitation problems, which seriously affect women's ability to provide resources for themselves and their families. Forests supply food, water, and medicinal and cultural resources, and their destruction endangers the livelihood and health of the communities that depend on those materials. Women often work as the managers of household resources, and their workload elevates as they must find new sources of food and resources to support their families by travelling farther and spending more time addressing the scarcity of resources. Being a coastal area, the Sundarbans often face severe cyclonic events, flood, saline water intrusion, soil erosion and so on. During these extreme events, the women encounter sanitation problems especially if they are menstruating or are pregnant. The change in climate brings changes in agricultural production and marine fishing. This results in decrease in income as these two are the main occupations in the Sundarbans. Declining income leads to migration of male members to other states, other countries. In absence of male members, the female members have to take care of the whole family, have to provide social security, and earn money by doing odd jobs. So, the burden becomes heavier for women. Though women constitute half of the world's population, tolerate severe gendered impacts of climate change but they do not have equal representation in Government's decision-making or policy making programmes throughout the world. The present paper wants to explore that how gender is related to climate change. The paper also has tried to locate the impacts of climate change on the women of Sundarbans. How the problems intervene in their biological, socioeconomical levels? The existing literature on climate change lacks a widespread discussion on gender and climate change. The perspective of women regarding climate change in Sundarbans has not been explored much. Women face unique and sometimes disproportionate burdens as a result of changing climate. On the other hand, women can address the issue of climate change from different perspectives through indigenous knowledge. They can take significant role in policy making. This less explored area has a remarkable potential for further research.

Keywords: Women, Climate Change, Sundarbans.

Copyright (C) 2021 The Author(s): This is an open-access article distributed under the terms of the Creative Commons Attribution 4.0 International License (CC BY-NC 4.0) which permits unrestricted use, distribution, and reproduction in any medium for non-commercial use provided the original author and source are credited.

\section{INTRODUCTION}

The United Nations Framework Convention on Climate Change (UNFCCC) defines climate change as "a change of climate which is attributed directly or indirectly to human activity that alters the composition of the global atmosphere and which is in addition to other natural climate variability that has been observed over comparable time periods" [1]. Climate change is a process that includes rise in average temperatures; changes in rainfall patterns leading to floods, droughts, and, in some areas, desertification. Extreme and unpredictable weather patterns bring more numerous and intense natural disasters. Melting of glaciers and the polar ice-caps, results in rising sea-levels and coastal erosion, which ultimately make the low-lying areas uninhabitable [2]. Along with it, Climate change is being increasingly accepted as a social phenomenon across societies. The women and the men experience climate change differently [3]. The women, compared to the men, are more vulnerable to climate change because the women comprise the majority of the world's poor. Additionally, for livelihood, the women are more dependent on natural resources to which climate change poses a threat [4]. The women of 
Sundarbans, India are not spared from the effect of climate change. The existing literature on climate change lacks a widespread discussion on gender and climate change. The perspective of women regarding climate change in Sundarbans has not been explored much. The present paper wants to understand the linkage between gender and climate change. The paper also has tried to assess the impacts of climate change on the women of Sundarbans.

\section{The problem}

Climate change is a threat to world's peace, security, and prosperity. The impacts of climate change are drought, flood, extreme weather, increased incidence of diseases, growing food insecurity and water insecurity which disproportionately distress 1.3 billion poor of the globe and among them, the majority are women. The women of Sundarbans, India are not spared from the effect of climate change. Flood and sea level rise demolish crop production and cause sanitation problems, which seriously affect women's ability to provide resources for themselves and their families. Forests supply food, water, and medicinal and cultural resources, and their destruction endangers the livelihood and health of the communities that depend on those materials. Women often work as the managers of household resources, and their workload elevates as they must find new sources of food and resources to support their families by travelling farther and spending more time addressing the scarcity of resources. Being a coastal area, the Sundarbans often face severe cyclonic events, flood, saline water intrusion, soil erosion and so on. During these extreme events, the women encounter sanitation problems especially if they are menstruating or are pregnant. The change in climate brings changes in agricultural production and marine fishing. This results in decrease in income as these two are the main occupations in the Sundarbans. Declining income leads to migration of male members to other states, other countries. In absence of male members, the female members have to take care of the whole family, have to give social security, and have to earn money by odd jobs. So, the burden becomes heavier for women. Though women constitute half of the world's population, tolerate severe gendered impacts of climate change but they do not have equal representation in Government's decision-making or policy making programmes throughout the world.

\section{MAJOR OBJECTIVES}

The major objectives of the paper are-

- To explore how gender is related to climate change.

- To identify the impacts of climate change on the women of Sundarbans.

- To analyze how the problems intervene in their biological, socio-economical levels.

\section{METHODOLOGY}

To retrieve the perspective of climate change and gender, an influx of relevant literatures has been taken under consideration to obtain relevant secondary data. On the basis of the secondary information, the analysis of impacts of climate change on gender and specifically on the women of Sundarbans has been conducted.

\section{ANALYSIS AND FINDINGS Gender and Climate}

Changing climate has impacts on women in different aspects. These aspects are discussed below-

\section{Sea Level Rise and Flooding}

Flooding and sea level rise demolish crop production and cause sanitation problems, which seriously damage women's ability to provide resources for themselves and their families. Predictions of Intergovernmental Panel on Climate Change indicate that during the twenty-first century, global warming will persist and will accelerate, estimating a temperature rise of three degrees Celsius by 2100. Increasing temperatures strengthen the hydrologic cycle causing dry areas to become drier and wet areas to become wetter. Sea level rise happens because of the thermal expansion of the ocean, and through the melting of glaciers and ice sheets caused by rising atmospheric temperatures. Global sea levels rose at a rate of approximately $1.7 \mathrm{~mm}(+/-0.3 \mathrm{~mm})$ per year from 1950 to 1992 , and at an average rate of approximately 3.3 $\mathrm{mm}(+/-0.4 \mathrm{~mm})$ per year from 1993 to 2009 . Sea level rise elevate salinity of the soil and declined crop yields in cultivated areas, drinking water impairment from salinity intrusion into coastal aquifers, soil erosion, and loss of fish habitat and reduced fish production, damage to coastal infrastructure, and loss of territory [5].

In Cotonou, Benin, in West Africa, sea level rise is mounting the risk of the resurgence of endemic tropical diseases as a result of the development of breeding grounds for anopheles mosquitoes, which spread malaria, and tsetse fly larvae, which have adapted to salt water. These may cause a boost in cardiovascular and cerebral diseases related to high saline levels in the water, which could increase mortality rates, especially among pregnant women, children and elderly people. Salinity in drinking water has been found to be attached with gestational hypertension in coastal communities. In low-income countries, hypertensive disorders can lead to maternal and perinatal death. It is evident that the coastal communities of low-income countries are disproportionately affected by the rising salinity of water [6].

A warmer climate and the associated increased climate variability will increase the risk of floods. On average 20 percent of the world's population resides in river basins that are likely to be affected by flood, with the rise of global temperatures, by the 2080s. For example, Bangladesh experiences frequent extreme flooding. Floods bring loss of life, an increase in 
disease, loss or destruction of property, and damage to agricultural production. People face water-borne diseases, such as diarrhea, cholera, typhoid, and skin rashes, in the aftermath of a flood. Women confront severe vulnerability due to various circumstantial and structural factors. In a study of women in Bangladesh impacted by floods, Azad, Hossain, and Nasreen found that nearly 61 percent of those surveyed were driven out from their normal dwellings in times of severe floods, and the sanitation facilities of 21 percent were damaged. They also found that 89 percent of the women surveyed became sick from wearing wet clothing, as they did not have adequate spare clothing. Women are also vulnerable to sexual and other harassment-such as mental torture, verbal abuse, and domestic violence - in the wake of a flood [7].

Individuals and communities around the world depend on natural resources found in forests and coastal areas for subsistence and shelter. Forests supply food, water, and medicinal and cultural resources, and their destruction threatens the livelihoods and health of the communities that depend on those materials. As these resources lessen, food insecurity and livelihood instability grow up. Women often work as the managers of household resources, and their burdens are likely to become significantly heavier as they must find new sources of food and resources to support their families, travelling farther and expenses more time addressing the resources scarcity.

\section{Ocean Acidification}

Ocean acidification means changes in ocean chemistry that occur as a result of carbon dioxide (CO2) emissions. The oceans absorb about one quarter of the carbon dioxide released into the atmosphere every year. The CO2 absorbed by the oceans makes seawater more acidic which ultimately affects the formation of the hard parts of corals and some shellfish, which destroys tropical reefs. Tropical reefs help approximately 25 percent of marine fish species, and provide food and livelihood for nearly 500 million people worldwide [5]. Ocean acidification is a substantial threat to food security [8]. Declining production at local fisheries thus has multiple negative consequences such as fish and seafood become less available, many families and communities may also have fewer socioeconomic resources to replace these cheap and easily accessible food sources in their diet. The effects of ocean acidification on women have been not been studied much. It is shown in the studies that as the food resources diminish and livelihoods are threatened, often women become responsible for finding replacement resources and may receive a disproportionately small share of those resources [8].

\section{Water Scarcity}

Climate change negatively affects water supplies around the world. Changes in temperature patterns, rainfall, solar radiation, and winds are raising the desertification of land. In Latin America, for example, severe water shortage problems have already been recognised in Bolivia, Colombia, Ecuador, and Peru. Both higher temperatures and lack of water in the soil can lessen crop productivity.

Water scarcity can also lead to the depletion of crops and deterioration of soil properties. Desertification of pastoral lands leads to the death of livestock. All these problems related to water security negatively impact on women [9].

Lack of access to clean drinking water disproportionately impacts women. In many communities around the world, women and girls bear the primary burden of finding water. This water needs for the basic needs like drinking, cooking, cleaning etc. Throughout the world, women and children collectively spend 140 million hours per day for gathering water for their families and communities, resulting in lost productive potential. They could have used that through income-generating jobs, caring for family members, or attending school. It also increases the risk of sexual violence for women and girls [10].

\section{Agricultural Production}

Women, who consist of the majority of the global agricultural workforce including in between 45 and 80 percent in developing countries; must cope up with the increased instances of drought and desertification. When the income reduces in agriculture due to changing climate, men incline to leave their communities in search for employment outside of cultivating crops. Women become the heads of households and have to take the responsibilities traditionally assigned to men, but often do not have the same authority, decision-making power, or access to community services, education, or financial resources [11]. Hunger and malnutrition make women physically weak which diminish productivity.

\section{Health and Sanitation}

In today's life, more people are likely to have access to a mobile phone than a toilet. Several poor people do not have proper sanitation and hygiene facilities in developing countries. Water scarcity compromises hygiene, particularly for women and girls, who may need it more than men, especially during pregnancy and menstruation. Lack of adequate access to safe water and sanitation is a significant factor in maternal and child mortality [12]. Increasing temperature and changing rainfall pattern lead to grow vector-borne diseases, such as malaria or dengue fever especially in India. Poor women are more likely to bear the brunt of these types of health problems because of their limited access to health facilities, low awareness of risks [13].

\section{Climate-Related Migration \& Displacement}

Climate change effects on the security and livelihoods of people around the world. In hope of 
finding safer environments, more stable economic opportunities, and long-term adaptation solutions, people with their families move, sometime voluntarily, sometime forcibly by the impacts of climate change, or as part of planned relocation. It is important to understand the impacts of migration on women.

Climate change can bring massive displacement. This type of displacement will have major impacts on the political, economic, and social aspects of people around the world. Though migration can bring better environment to the people but it may call several risks associated with climate changeinduced migration, especially for women. In order to reach a country where they can seek asylum, many must trust on smugglers, resort to desperate measures, and endure perilous routes. Women and adolescent girls may be forced to trade sex with border guards and others in return for permission to pass, and they face a greater risk of being trafficked for sex work and other types of bonded labour [14]. In refugee and internally displaced person (IDP) camps, women have no opportunity to employment, lack privacy, and have limited participation in decision-making processes. Sexual and gender-based violence is known to be rampant in camps, including domestic violence. After settling in urban area, Women are in threat of arrest and deportation due to lack of identification papers.

\section{The Condition of Women in Sundarbans due to Climate Change}

The Sundarbans consists of 54 islands and it is home of about 4 million people. The inhabitants suffer from poverty, deprivation, risky life. Due to harsh geographical challenges, the islanders have to survive on subsistence-level return from diminishing natural endowments. They depend on rain-fed / mono-crop agriculture, the forest (for forest products) and the rivers / estuaries (for fishing) which have meagre support to income. Ironically, the area which is surrounded only by water, experience chronic lack of safe drinking water since the river water is salty and of no use for drinking [15].

Being a coastal area, the Sundarbans often face severe cyclonic events, flood, saline water intrusion, soil erosion and so on. Due to these weather events, people lose their houses have to live temporary house made out of dalma/ clay. These houses are not equipped with proper toilets. It lacks clean water. Women bear the brunt of it. This lack of access to hygienic sanitation makes them vulnerable physically. They are susceptible to diseases. If the women are menstruating then the situation become worse. During sudden water intrusion, inhabitants have to move to safer places for survival and it can be imaginable how difficult it is for pregnant women to move in this situation. The change in climate brings changes in agricultural production and marine fishing. This results in decrease in income as these two are the main occupations in the Sundarbans. Declining income leads to migration of male members to other states, other countries. In absence of male members, the female members have to take care of the whole family, have to give social security, and have to earn money by odd jobs. So, the burden becomes heavier for women [16].

Climate change and climate change-related migration is also related to human trafficking. Traffickers often exploit the migrants. People leave their home because of poverty and unemployment, criminal violence, armed conflict, or natural disasters, which can make them vulnerable to exploitation [17]. As climate change impacts physical and social environments and the incidence of natural disasters elevate, more people will mobilize and may be at risk of being trafficked. Women are forced to prostitution. In Dholkhali, located in the Sundarbans on the eastern coast of the Indian subcontinent, the climate change is the reason for increasing human trafficking rates. The accumulated effects of poverty and climate change extend the traffickers' ability to lure women and children into forced prostitution, marriage, and labour. Cyclone Aila, which evacuated more than a million people in May 2009, catalyzed trafficking. The issue can become terrible as the Sundarbans coastline is retreating about 650 feet per year, and much of the islands could be underwater in 15 to 25 years [18].

\section{CONCLUSION}

After the discussion, it can be concluded that climate change affects gender. The change in climate brings environmental changes but those changes severely impact on women in their socio-economical and physical levels. The women of Sundarbans are not immune to those effects. Saline water intrusion, cyclone, soil erosion make them vulnerable in their health. Change in rainfall pattern, water scarcity lead to less income in agriculture which bring burden to the women's life. Ocean acidification brings changes in fishing community which ultimately affects women fishers. Declining income make the male members to migrate for other occupations. This results in taking of more household responsibilities among women. They also have to do odd jobs for supplement the income. Another aspect of climate change is environmental migration. This migration makes the women susceptible to women trafficking. Here, the question arises how to improve the situation?

\section{RECOMMENDATION}

For this paper few points are recommended-

- Lack of independence and decision making power restrict women's ability to adapt to climate change. Women often have limited or no control over family finances and assets. Though women constitute half of the world's population, tolerate severe gendered impacts of climate change but they do not have equal representation in Government's decision-making or policy making programmes 
throughout the world. Women should bring in the climate change related policy making scenario. They can give significant indigenous knowledge regarding adaptation strategies.

- The aid given to the people after natural disasters should be gendered. The aids should include sanitary pads, undergarments for women, clothing.

- Water scarcity is one of the significant problems for women. This problem should be eradicated by proper scientific technologies.

- Trafficking of Women is a vulnerable issue throughout the world. Strict laws should be implemented.

\section{REFERENCES}

1. UNFCCC 1992. Available from https://unfccc.int/files/essential_background/backgr ound_publications_htmlpdf/application/pdf/conven g.pdf

2. UNHCR. Handbook for the Protection of Women and Girls. 2008; 8. Available from http://www.unhcr.org/47cfa9fe2.html.

3. IUCN. Gender and Climate Change Strengthening Climate Action by Promoting Gender Equality. 2015. Available from https://www.iucn.org/sites/dev/files/import/downlo ads/gender_and_climate_change_issues_brief_cop2 1__04122015.pdf

4. UN Women Watch. Women, Gender Equality and Climate Change. 2009. Available from https://www.un.org/womenwatch/feature/climate_c hange/downloads/Women_and_Climate_Change_F actsheet.pdf

5. United Nations Framework Convention on Climate Change. Slow Onset Events: Technical Paper. 2012; 9-10. Available from http://unfccc.int/resource/docs/2012/tp/07.pdf.

6. Khan AE, Scheelbeek PFD, Shilpi AB, Chan Q, Mojumder SK, Rahman A, Haines A, Vineis P. Salinity in drinking water and the risk of (pre)eclampsia and gestational hypertension in coastal Bangladesh: a case-control study. PLOS One. 2014; 9(9): e108715.

7. Azad AK, Hossain KM, Nasreen M. Flood-Induced Vulnerabilities and Problems Encountered by Women in Northern Bangladesh. International Journal of Disaster Risk Science. 2013; 4(4): 191193.

8. Huelsenbeck M. Ocean-based Food Security Threatened in High CO2 World. Oceana. 2012 Available from http://oceanacidification.co.uk/pdf/1acid_final_091 812-pdf.pdf.
9. Abuya J. How the Drought Affects Women. ActionAid USA. 2011. Available from http://www.actionaidusa.org/2011/07/how-droughtaffects-women.

10. WHO and UNICEF. Progress on Sanitation and Drinking-Water: 2010 Update (Joint Monitoring Programme (JMP) for Water Supply and Sanitation, 2010). 2010. Available from http://www.unicef.org/eapro/JMP-2010Final.pdf.

11. United Nations International Fund for Agricultural Development. Gender and Desertification: Making Ends Meet in Drylands. 2010; 2. Available from https://www.ifad.org/documents/38714170/391356 45/Gender+and+desertification+-

+Making+ends+meet+in+drylands.pdf/31c1e9794dc5-497a-9f59-ebafc0b36526.

12. Mahon T, Fernades M. Menstrual Hygiene in South Asia: A Neglected Issue for WASH Programmes. Gender \& Development. 2010; 18(1): 102-103.

13. WHO. Gender, Climate Change and Health. 2014; $3 . \quad$ Available from http://apps.who.int/iris/bitstream/10665/144781/1/9 789241508186_eng.pdf?ua=1.

14. United Nations High Commissioner for Refugees. Climate Change, Natural Disasters, and Human Displacement: A UNHCR Perspective. 2009. Available from http://www.unhcr.org/4901e81a4.html.

15. Kanjilal B, Mandal A, Barman D, Mukherjee M, Mazumder PG, Mandal S, Singh S. Health care in the Sundarbans: Challenges and plan for a better future. 2010. Available from https://assets.publishing.service.gov.uk/media/57a0 8b24ed915d3cfd000b68/sundarbans.pdf.

16. Priyadarshini S. Climate change pushing Sundarban farmers into 'awkward jobs'. Nature India. 2015. doi:10.1038/nindia.2015.21. Available from

https://www.natureasia.com/en/nindia/article/10.10 38/nindia.2015.21.

17. United States Department of State. Trafficking in Persons Report. 2015; 17. Available from https://2009-

2017.state.gov/documents/organization/245365.pdf

18. Eaton S. After the Floods Come the Human Traffickers, But These Girls are Fighting Back. PRI's TheWorld. Public Radio International. 2015. Available from http://www.pri.org/stories/2015-0915/after-floods-come-human-traffickers-thesegirls-are-fighting-back. 